Sains Malaysiana 50(11)(2021): 3455-3465

http://doi.org/10.17576/jsm-2021-5011-27

\title{
Evaluation of the Confidence and Competency of House Officers in Rapid Sequence Intubation (ECCHO-RSI) in Emergency Department of Hospital Canselor Tuanku Muhriz, Universiti Kebangsaan Malaysia Medical Centre during COVID-19 Pandemic
}

(Penilaian Keyakinan dan Kekompetenan Pegawai Perubatan dalam Intubasi Urutan Pantas (ECCHO-RSI) di Jabatan Kecemasan Hospital Canselor Tuanku Muhriz, Pusat Perubatan Universiti Kebangsaan Malaysia semasa Pandemik COVID-19)

\author{
Kevin Chuing Shen Wong, Ahmad Khaldun Ismail*, Siti Sarah Md Zhahir, Ida Zarina Zaini
}

\section{ABSTRACT}

Rapid sequence intubation (RSI) is a procedural skill that house officers (HO) in Malaysia need to learn during their training in emergency department (ED) posting. This study aimed to evaluate the confidence and competency of HO in RSI after completed training in the ED of a university hospital during the COVID-19 pandemic. A prospective cross-sectional study was conducted among $44 \mathrm{HO}$. When they begin their posting in ED, a pre-test was done with a questionnaire to evaluate their knowledge and confidence level. A post-test was conducted three months later with a similar questionnaire. They underwent an objective structured clinical examination to evaluate their skill. A feedback survey form was filled in by the HO regarding their satisfaction in training in emergency rotation. The mean score for pre-test and posttest were $8.75 \pm 3.005$ and $14.86 \pm 2.258$, respectively $(P=0.000)$. There was an improvement in knowledge level and confidence level between pre-test and post-test (all $P=0.000$ ). $43.2 \%$ were competent in knowledge, while $65.9 \%$ were competent in skill. 35 house officers filled in the feedback survey form. It showed that $42.9 \%(n=15)$ were very satisfied and $28.6 \%(n=10)$ were satisfied with the training in ED. There was an improvement in knowledge and confidence level in RSI among the HO after ED rotation. The clinical exposure in intubating real patients was limited among HO due to the COVID-19 pandemic. The training of HO for RSI in ED needs to be further improvised to optimize their learning process.

Keywords: COVID-19; internship and residency; rapid sequence intubation; teaching and learning; workplace learning

ABSTRAK

Intubasi Urutan Pantas (RSI) adalah kemahiran prosedur yang perlu dipelajari pegawai perubatan siswazah (PPS) di Malaysia semasa menjalani latihan di Jabatan Kecemasan (ED). Kajian ini bertujuan untuk menilai tahap keyakinan dan kecekapan melakukan RSI dalam kalangan PPS yang telah melengkapkan latihan di jabatan kecemasan sebuah hospital universiti semasa pandemik COVID-19. Kajian prospektif ini dijalankan dalam kalangan 44 PPS di ED. Semasa mereka memulakan latihan di ED, ujian pra dilakukan dengan borang soal selidik untuk menilai tahap pengetahuan dan keyakinan mereka dalam RSI. Selepas tiga bulan, ujian pasca dijalankan dengan soal selidik. Mereka menduduki pemeriksaan klinikal berstruktur objektif RSI untuk menilai tahap kemahiran mereka. Borang tinjauan maklum balas diisi oleh HO mengenai kepuasan mereka mengenai latihan di ED. Skor min ujian pra dan ujian pasca masing-masing adalah $8.75 \pm 3.005$ dan $14.86 \pm 2.258(P=0.000)$. Terdapat peningkatan tahap pengetahuan dan keyakinan antara ujian pra dan ujian pasca (semua $P=0.000) .43 .2 \%(n=19)$ mempunyai kompetensi dalam pengetahuan, sementara $65.9 \%(n=$ 29) kekompetenan dalam kemahiran. 35 PPS mengisi borang tinjauan maklum balas. Keputusan menunjukkan bahawa 42.9\% $(n=15)$ sangat berpuas hati dan 28.6\% $(n=10)$ berpuas hati dengan latihan di ED. Kajian ini menunjukkan bahawa setelah menjalani latihan di ED, terdapat peningkatan dalam tahap pengetahuan dan keyakinan dalam RSI dalam kalangan PPS. Pendedahan klinikal untuk intubasi pesakit sebenar adalah terhad dalam kalangan PPS disebabkan pandemik COVID-19. Latihan PPS untuk RSI di ED perlu diperbaiki untuk pembelajaran yang optimum.

Kata kunci: COVID-19; intubasi; latihan siswazah; pembelajaran di tempat kerja; pengajaran dan pembelajaran 


\section{INTRODUCTION}

In Malaysia, the new house officers (HO) who graduated from medical school shall undergo housemanship training with a provisional registration to gain experience (Malaysian Medical Council (MMC) 2008). During the training as HO, they will undergo six rotations in internal medicine, paediatrics, surgery, orthopaedic, obstetrics and gynaecology, and emergency medicine or anaesthesiology. They will receive logbooks from the Medical Qualifying Board. During each respective rotation, they should achieve competency in performing procedures which are required in the logbook (MMC 2008).

Rapid sequence intubation or rapid sequence induction (RSI) is the administration, after preoxygenation, of a potent induction agent followed immediately by a rapidly acting neuromuscular blocking agent to induce unconsciousness and motor paralysis for endotracheal intubation (Walls 2012). It is an important life-saving procedure in the emergency department (ED) for patients with risk of aspiration and compromised airway or requiring mechanical ventilation. RSI is one of the procedural skills that HO need to learn during their training. The knowledge and skill to performed RSI should be acquired when HO had their training in ED before they become medical officers.

World Health Organization (WHO) had declared coronavirus disease (COVID-19) a pandemic on 11 March 2020 (Cucinotta \& Vanelli 2020). Since then, the ED of Hospital Canselor Tuanku Muhriz (HCTM), Universiti Kebangsaan Malaysia (UKM) had a change of workflow and standard operating procedure especially for patients who came to ED with severe acute respiratory infection (SARI). These changes had an impact on HO training in airway management. They were not allowed to work in the respiratory resuscitation zone or participate in the intubation of patients with SARI to reduce the risk of transmission of COVID-19 among HO. SARI patient was intubated by the most experienced medical officer to increase the chance of first-pass success.

This study aimed to determine whether the HO who had completed the ED rotation in HCTM during COVID-19 pandemic were confident and competent in performing RSI. This evaluation is important to guide the teaching and training of HO for RSI in ED of HCTM in the era of COVID-19 pandemic to ensure that these HO will be competent in performing RSI as medical officers.

\section{MATERIALS AND METHODS}

STUDY DESIGN

A prospective cross-sectional study was conducted in the ED of HCTM, UKM over a period of twelve months. HO who had entered training in the ED of HCTM were recruited into the study, but the HO who had previous training and working experience in the ED of other hospital were excluded.

This study was divided into two phases. The first phase of the study was the evaluation of demographic background, the confidence and knowledge level of the participants in RSI before training in the ED of HCTM using a questionnaire. The participants were asked to fill in the pre-test Google form, which contained the information sheet, consent form, and a questionnaire. The skill level of participants in RSI will not be evaluated because they do not have much opportunity to do RSI in the rotations in other departments.

The second phase of the study was the evaluation of the intubation experience, the confidence and knowledge level of the participants in RSI three months after training in the ED of HCTM using a similar questionnaire. The participants were asked to fill in the post-test Google form. After completion of the questionnaire, the participants will undergo an objective structured clinical examination (OSCE) on RSI to evaluate their skill in RSI.

\section{STUDY TOOLS}

The participants filled in the questionnaire in both the pre-test and post-test Google forms. The questionnaire has three sections: Section A was designed to explore the demographic background of the participants including age, gender, undergraduate education, number of rotations of housemanship completed, intubation experience, and exposure to airway management training; Section B was designed to assess the confidence level of participants in RSI. The assessment consisted of twelve statements which used a 5-point Likert scale with 1 (strongly disagree) as lowest to 5 (strongly agree) as the highest; and Section $\mathrm{C}$ was designed to assess the knowledge level of participants in RSI. There was a total of 20 multiple-choice questions (MCQ). Of the options, only one correct answer and others served as distracters. Each of the questions also had a 'Not sure' option. The score was in numerical points as in 1 is for the correct answer and 0 for 'Not sure' and incorrect answer. The percentage was applied to assess the knowledge level on RSI based on Bloom's cut off point (1956): low level $(<60 \%)$, moderate level $(60-79 \%)$, high level (80-100\%). The participant was considered as competent in knowledge if they score $80 \%$ and above. In the second phase of the study, the participants underwent an OSCE with a standard OSCE scenario for RSI where 
participants have to perform RSI on an airway mannequin (Laerdal® Airway Management Trainer) with an assistant who was a medical officer from ED of HCTM. The examiners assessed the participants using a standardized OSCE checklist. Two examiners were involved in the entire study, and they are the emergency physicians of HCTM. The OSCE checklist consisted of the steps that the participant needs to perform. The examiner will tick $(\sqrt{ })$ on the given box if the step was performed correctly. Upon completion of the OSCE, the examiner gave a global rating for each participant, either 'Good', 'Satisfactory' or 'Not satisfactory'. The participant was considered as competent in skill if they obtain 'Good' or 'Satisfactory' for the global rating. After completion of the questionnaire and OSCE, those participants who performed poorly (low knowledge level or 'Not satisfactory' during the OSCE) were called back for an additional counselling session.

The participants were requested to fill in a feedback survey Google form. This form was designed to assess the satisfaction and feedback from HO regarding the HO training in airway management and RSI in ED of HCTM, UKM.

\section{ETHICAL APPROVAL}

This study was commenced after the approval was obtained from the Research Ethics Committee UKM with the project code approval UKM PPI/111/8/JEP-2020-050. The research was conducted according to the standard of Good Clinical Practice. The participants were recruited in the study after they gave the consent to do so and will be allowed to withdraw from the study at any point. Records of the performance of the participants during the study were kept confidential and only accessible to the researcher.

\section{STATISTICAL ANALYSIS}

Statistical analysis for the study was performed using IBM SPSS Statistic version 22 (IBM Corp, Armonk, NY). The demographic characteristics and OSCE result were analysed with descriptive statistics. Data were summarized using median and interquartile range (IQR) for continuous variables; frequency (f) and percentages for categorical variables. A paired t-test was used to assess means difference between the pre-test and post-test score of the MCQ. Wilcoxon paired signed-rank test was used to assess the difference between pre-test and post-test for knowledge level and each statement on the confidence level. In all analyses, the difference was considered statistically very highly significant when the $P$-value was less than 0.001 .

\section{SAMPLE SIZE CALCULATION}

The sample size calculated by Krejcie and Morgan (1970) formula was 40 , assuming a response rate of $50 \%, 95 \%$ confidence interval, $\mathrm{Z}$ of 1.96 and margin of error of $5 \%$. A further $10 \%$ was added to counteract possible drop out of the sample, resulting in a final sample size of 44 .

\section{RESULTS AND DISCUSSION}

\section{RESULTS}

A total of 49 HO in ED of HCTM was eligible to participate in this study. They consented and were recruited into the first phase of the study. However, five of them were dropped out of the study as they were transferred to other hospitals before the second phase of the study. Hence, the final total number of participants that completed the study was 44 .

The demographic background of the participants was shown in Table 1 . They were aged between 26 and 31 years, with the median 27 (IQR 1). Education background showed $77.3 \%$ graduated from local universities (22.7\% from public and $52.3 \%$ from private). All had completed at least four clinical rotations during housemanship.

The comparison of the result of the pre-test and post-test for MCQ score, knowledge level, and confidence level of participants in RSI was shown in Tables 2, 3, and 4. For the knowledge component of the questionnaire, the mean score (out of 20) for pre-test and post-test were $8.75 \pm 3.005$ and $14.86 \pm 2.258$, respectively $(P=0.000)$. There was an improvement in knowledge level and confidence level in RSI among the participants (all $P=0.000)$. In the post-test result, $43.2 \%(\mathrm{n}=19)$ of the participants had high knowledge and was deemed as competent in knowledge.

The result of the OSCE in RSI was shown in Table 5. Majority $(65.9 \%, \mathrm{n}=29)$ of the participants were competent in skill, with $22.7 \%(\mathrm{n}=10)$ had 'Good' and $43.2 \%(n=19)$ had 'Satisfactory' performance for the global rating in OSCE.

The summary of the feedback from HO on training in airway management \& RSI in ED of HCTM was shown in Table 6. Out of 44 participants, 35 filled in this form, with $42.9 \%(n=15)$ were very satisfied and $28.6 \%(n=$ 10) were satisfied with the training in ED of HCTM. The majority $(88.6 \%, \mathrm{n}=31)$ were concerned that they have inadequate clinical exposure in intubating real patients. 
TABLE 1. Demographic background of participants

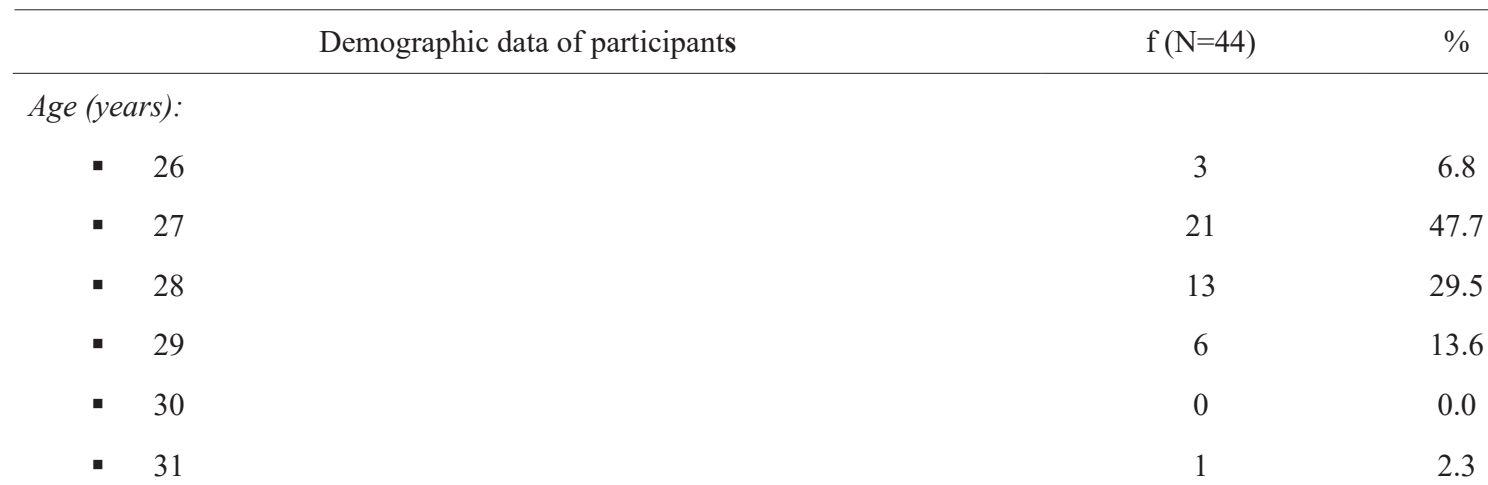

Gender:

- Male

- Female

Undergraduate university:

- Local (Public)

- Local (Private)

52.3

- Oversea

- Twining

6.8

Number of postings done previously:

- 4

- 5

Postings which had completed previously:

- Internal Medicine

100.0

- $\quad$ Surgery

- Obstetrics and Gynaecology

90.9

- Paediatric

- Orthopaedic

Attended airway management related course or course with airway management previously:

- Yes

- $\quad$ No 
Intubation experience before entering $E D$ :

- Number of intubation that observed/assisted

- 0

- $1-5$

- $\quad>5$

- Number of intubation attempts

- 0

- $1-5$

- $>5$

- Number of successful intubations

- 0

- $1-5$

- $\quad>5$

Intubation experience during ED posting:

- Number of intubation that observed/assisted

- 0

- $1-5$

- $\quad>5$

- Number of intubation attempts

- 0

- 1

- 2

- Number of successful intubations

- 0

Airway management training received in ED posting:

- $\quad$ Lecture during CME

- Hands-on practical session or simulation training on airway mannequin in skill lab

- Bedside teaching when working in ED

- DOPS evaluation 
TABLE 2. Comparison of pre-test and post-test result of multiple-choice questions (MCQ) of the participants using paired $t$ test

\begin{tabular}{|c|c|c|c|c|}
\hline Result & Mean Pre-Test Score (SD) & Mean Post-Test Score (SD) & $\begin{array}{c}\text { Test statistic } \\
\text { (df) }\end{array}$ & $P$-value \\
\hline $\begin{array}{l}\text { Total Score } \\
\text { (out of 20) }\end{array}$ & $8.75(3.005)$ & $14.86(2.258)$ & $12.235(43)$ & 0.000 \\
\hline Percentage & $43.75(15.024)$ & $74.32(11.289)$ & & \\
\hline
\end{tabular}

TABLE 3. Comparison of pre-test and post-test result on knowledge level of participants in RSI using Wilcoxon paired signed rank test

\begin{tabular}{|c|c|c|c|c|c|c|c|c|}
\hline \multirow{2}{*}{ Knowledge level } & \multicolumn{3}{|c|}{ Pre-Test } & \multicolumn{3}{|c|}{ Post-Test } & \multirow{2}{*}{$\begin{array}{c}\text { Test } \\
\text { statistics }\end{array}$} & \multirow[t]{2}{*}{$P$-value } \\
\hline & $\mathrm{f}(\mathrm{N}=44)$ & $\%$ & $\begin{array}{c}\text { Median } \\
\text { (IQR) }\end{array}$ & $\mathrm{f}(\mathrm{N}=44)$ & $\%$ & $\begin{array}{l}\text { Median } \\
\text { (IQR) }\end{array}$ & & \\
\hline $\begin{array}{l}1=\text { Low } \\
(<60 \%)\end{array}$ & 35 & 79.5 & $1(0)$ & 5 & 11.4 & $2(1)$ & -5.313 & 0.000 \\
\hline $\begin{array}{l}2=\text { Medium } \\
(60-79 \%)\end{array}$ & 9 & 20.5 & & 20 & 45.5 & & & \\
\hline $\begin{array}{l}3=\text { High } \\
(80-100 \%)\end{array}$ & 0 & 0.0 & & 19 & 43.2 & & & \\
\hline
\end{tabular}

TABLE 4. Comparison of pre-test and post-test outcome of each statement on confidence level of participants in RSI with Wilcoxon paired signed rank test

\begin{tabular}{|c|c|c|c|c|c|c|c|c|c|}
\hline & & & Pre-Test & & & Post- & & & \\
\hline Statements & $\begin{array}{l}\text { Likert } \\
\text { Scale }\end{array}$ & $\mathrm{f}(\mathrm{N}=44)$ & $\%$ & $\begin{array}{c}\text { Median } \\
\text { (IQR) }\end{array}$ & $\begin{array}{c}\mathrm{f} \\
(\mathrm{N}=44)\end{array}$ & $\%$ & $\begin{array}{c}\text { Median } \\
\text { (IQR) }\end{array}$ & $\begin{array}{l}\text { Iest Sta- } \\
\text { tis-tics }\end{array}$ & $P$-value \\
\hline \multirow{5}{*}{$\begin{array}{l}\text { S1. I know the } \\
\text { steps in per- } \\
\text { forming RSI. }\end{array}$} & 1 & 9 & 20.5 & \multirow[t]{5}{*}{$2(1)$} & 0 & 0.0 & \multirow[t]{5}{*}{$4(1)$} & \multirow[t]{5}{*}{-5.571} & \multirow[t]{5}{*}{0.000} \\
\hline & 2 & 15 & 34.1 & & 0 & 0.0 & & & \\
\hline & 3 & 16 & 36.4 & & 6 & 13.6 & & & \\
\hline & 4 & 4 & 9.1 & & 19 & 43.2 & & & \\
\hline & 5 & 0 & 0.0 & & 19 & 43.2 & & & \\
\hline \multirow{5}{*}{$\begin{array}{l}\text { S2. I know the } \\
\text { indications to } \\
\text { perform RSI. }\end{array}$} & 1 & 4 & 9.1 & \multirow[t]{5}{*}{$3(1)$} & 0 & 0.0 & \multirow[t]{5}{*}{$4(1)$} & \multirow[t]{5}{*}{-5.068} & \multirow[t]{5}{*}{0.000} \\
\hline & 2 & 14 & 31.8 & & 0 & 0.0 & & & \\
\hline & 3 & 16 & 36.4 & & 5 & 11.4 & & & \\
\hline & 4 & 10 & 22.7 & & 20 & 45.5 & & & \\
\hline & 5 & 0 & 0.0 & & 19 & 43.2 & & & \\
\hline
\end{tabular}


S3. I am able to preoxygenate the patient during RSI.

S5. I know the dosage of the sedative agents in RSI.

S6. I know the dosage of the paralytic agents in RSI.

S7. I am able to prepare the equipment needed for RSI
2.3

43.2

31.8

18.2

4.5

11.4

47.7

36.4

4.5

0.0

36.4

45.5

13.6

2.3

2.3

38.6
45.5
15.9
0.0
0.0

$2(1)$

$2(1)$

$2(1)$

$3(1)$

0

0.0

4 (1)

$-5.156$

0.000

$\begin{array}{ll}0 & 0.0\end{array}$

$\begin{array}{ll}6 & 13.6\end{array}$

$20 \quad 45.5$

18

40.9
$0 \quad 0.0$

$1 \quad 2.3$

24.5

$26 \quad 59.1$

$15 \quad 34.1$

$\begin{array}{ll}4(1) \quad-5.698 & 0.000 \\ & \end{array}$

$4(2) \quad-5.534 \quad 0.000$
$1 \quad 2.3$

$9 \quad 20.5$

$23 \quad 52.3$

$11 \quad 25.0$<smiles>CCCCC</smiles>

$4(2) \quad-5.704 \quad 0.000$ $\begin{array}{ll}1 & 2.3\end{array}$

$13 \quad 29.5$

$19 \quad 43.2$

$11 \quad 25.0$ 


\begin{tabular}{|c|c|c|c|c|c|c|c|c|c|}
\hline \multirow{5}{*}{$\begin{array}{l}\text { S9. I am con- } \\
\text { fident with my } \\
\text { intubation skill. }\end{array}$} & 1 & 18 & 40.9 & \multirow[t]{5}{*}{$2(1)$} & 1 & 2.3 & \multirow[t]{5}{*}{$3(1)$} & \multirow[t]{5}{*}{-5.490} & \multirow[t]{5}{*}{0.000} \\
\hline & 2 & 19 & 43.2 & & 7 & 15.9 & & & \\
\hline & 3 & 7 & 15.9 & & 22 & 50.0 & & & \\
\hline & 4 & 0 & 0.0 & & 10 & 22.7 & & & \\
\hline & 5 & 0 & 0.0 & & 4 & 9.1 & & & \\
\hline \multirow{5}{*}{$\begin{array}{l}\text { S10. I am able } \\
\text { to identify all } \\
\text { possible causes } \\
\text { of post-intuba- } \\
\text { tion desaturation }\end{array}$} & 1 & 5 & 11.4 & \multirow[t]{5}{*}{$2(1)$} & 0 & 0.0 & \multirow[t]{5}{*}{$4(1)$} & \multirow[t]{5}{*}{-5.148} & \multirow[t]{5}{*}{0.000} \\
\hline & 2 & 20 & 45.5 & & 3 & 6.8 & & & \\
\hline & 3 & 16 & 36.4 & & 11 & 25.0 & & & \\
\hline & 4 & 3 & 6.8 & & 22 & 50.0 & & & \\
\hline & 5 & 0 & 0.0 & & 8 & 18.2 & & & \\
\hline \multirow{5}{*}{$\begin{array}{l}\text { S11. I am able } \\
\text { to identify dif- } \\
\text { ficult airway. }\end{array}$} & 1 & 8 & 18.2 & \multirow[t]{5}{*}{$2(1)$} & 0 & 0.0 & \multirow[t]{5}{*}{$3(1)$} & \multirow[t]{5}{*}{-4.410} & \multirow[t]{5}{*}{0.000} \\
\hline & 2 & 17 & 38.6 & & 6 & 13.6 & & & \\
\hline & 3 & 15 & 34.1 & & 17 & 38.6 & & & \\
\hline & 4 & 4 & 9.1 & & 14 & 31.8 & & & \\
\hline & 5 & 0 & 0.0 & & 7 & 15.9 & & & \\
\hline \multirow{5}{*}{$\begin{array}{l}\text { S12. I am confi- } \\
\text { dent to perform } \\
\text { RSI on a real } \\
\text { patient in future } \\
\text { as a medical } \\
\text { officer. }\end{array}$} & 1 & 17 & 38.6 & \multirow[t]{5}{*}{$2(1)$} & 1 & 2.3 & \multirow[t]{5}{*}{$3(1)$} & \multirow[t]{5}{*}{-5.465} & \multirow[t]{5}{*}{0.000} \\
\hline & 2 & 17 & 38.6 & & 5 & 11.4 & & & \\
\hline & 3 & 10 & 22.7 & & 17 & 38.6 & & & \\
\hline & 4 & 0 & 0.0 & & 18 & 40.9 & & & \\
\hline & 5 & 0 & 0.0 & & 3 & 6.8 & & & \\
\hline
\end{tabular}

Likert Scale: $1=$ Strongly disagree, $2=$ Disagree, $3=$ Neutral, $4=$ Agree, $5=$ Strongly agree

TABLE 5. RSI OSCE result of the participants

\begin{tabular}{|c|c|c|}
\hline Global Rating of OSCE & Frequency $(\mathrm{N}=44)$ & $\%$ \\
\hline Not satisfactory & 15 & 34.1 \\
\hline Satisfactory & 19 & 43.2 \\
\hline Good & 10 & 22.7 \\
\hline
\end{tabular}


TABLE 6. Summary of feedback from HO on training in airway management \& RSI in ED of HCTM, UKM

\begin{tabular}{|c|c|c|}
\hline Questions & $\mathrm{f}(\mathrm{N}=35)$ & $\%$ \\
\hline \multicolumn{3}{|c|}{$\begin{array}{l}\text { Are you satisfied with the HO training in airway management and RSI in ED posting of } \\
\text { HCTM, UKM? }\end{array}$} \\
\hline - 1 - Very not satisfied & 0 & 0 \\
\hline - 2 - Not satisfied & 0 & 0 \\
\hline - 3 - Neutral & 10 & 28.6 \\
\hline - 4 - Satisfied & 10 & 28.6 \\
\hline - 5 - Very satisfied & 15 & 42.9 \\
\hline \multicolumn{3}{|c|}{ What is lacking in the HO training in airway management and RSI in ED of HCTM, UKM? } \\
\hline - Inadequate clinical exposure in intubating real patients & 31 & 88.6 \\
\hline - Inadequate teaching session in RSI and airway management & 7 & 20.0 \\
\hline - Inadequate hands-on session on airway mannequin & 9 & 25.7 \\
\hline - Other & 1 & 2.9 \\
\hline \multicolumn{3}{|c|}{$\begin{array}{l}\text { What additional training/teaching or improvement do you think will be helpful in HO training } \\
\text { in airway management and RSI in ED of HCTM, UKM? }\end{array}$} \\
\hline - More lecture or CME on RSI and airway management & 5 & 14.3 \\
\hline - Use pre-recorded video lecture & 6 & 17.1 \\
\hline - Airway course in the department with practical session & 29 & 82.9 \\
\hline - Simulation training on airway mannequin & 18 & 51.4 \\
\hline - Other & 3 & 8.7 \\
\hline
\end{tabular}

\section{DISCUSSION}

During the rotation in ED of HCTM, on top of the daily clinical work and clinical exposure in the department, HO are given training in emergency airway management and RSI through different modalities. Lectures on the topic of emergency airway management were given during continuous medical education (CME). Some HO have hands-on sessions on airway mannequin and bedside teaching where skills on airway management such as bag-mask ventilation, laryngoscopy, and intubation were demonstrated and HO can practice on it. RSI is one of the compulsory performed procedures under direct observation of procedural skills (DOPS) assessment that needs to be completed in the logbook. All the HO need to have the DOPS assessment done before completion of ED rotation, but some of them were recruited into the second phase of this study before the DOPS evaluation was done.

When the HO were working in the ED of HCTM, majority of them observed intubation procedure. However, only a few of them had the experience of intubating real patient. Many HO mentioned in the feedback survey form that they had inadequate clinical exposure in intubating real patient. The new workflow and standard operating procedure in ED during COVID-19 pandemic prohibit HO to intubate SARI patient. Hence, the chance of exposure to airway management and endotracheal intubation for HO was low during COVID-19 
pandemic. The trainees or learners might not achieve their competencies within the usual timeframes during COVID-19 pandemic (Cleland et al. 2020).

The training that each $\mathrm{HO}$ received was not uniform because they entered the rotation in different timing. Although the attendance for the department CME is compulsory, some of them might have missed the CME on the topic of airway or RSI during their rotation in ED. Bedside teaching and hands-on practical session were subjected by the initiative from the HO and also the medical officers that they were working with. The high patient load in ED might be a hindrance for bedside teaching session to be done during their working time, and the 12-hour shift also a possible factor that discourages the HO to have teaching session outside of the working hour.

There was a significant improvement in knowledge level in RSI after three months of training in ED rotation. It can be contributed by both the training during ED rotation and their initiative to read up on RSI. Since all HO have to undergo the DOPS evaluation with the emergency physicians before completing the ED rotation, this might increase the motivation of the HO to study on RSI as a preparation before the DOPS.

The confidence level of HO in RSI increased after three months of training in ED, possibly due to the clinical exposure when working in the ED. Abd Samat et al. (2020) demonstrated that emergency healthcare workers with longer length of service in were showing better confidence in airway management and resuscitation of suspected COVID-19 patients. Some of the HO had the opportunity to have hands-on practical sessions in the skill lab, and some had undergone the DOPS evaluation, which involved a clinical scenario that requires HO to perform RSI on an airway mannequin. Simulation training is a technique that aims to replicate the real experience which is immersive in nature, and such training can increase the confidence level of the participants (Lateef 2010; Toy et al. 2017). The training that our HO had on the airway mannequin might be a contributing factor that improved their confidence level in RSI.

Other studies showed improvement of knowledge, confidence, and skill in airway management after a teaching or training session. In a study by Makwana et al. (2016), 50 interns underwent a training session which consisted of lecture and one-to-one demonstration and practice of mannequin. There was an improvement of knowledge, with the mean of the marks for pre-test and post-test were $8.12 \pm 1.63$ and $13.86 \pm 1.06$, respectively. $90 \%$ of the interns able to intubate in the first or second attempt during DOPS evaluation. Makwana et al.
(2016) emphasized the importance of endotracheal intubation training and it can be carried out with lecture and demonstration of procedural skill (laryngoscopy, intubation, and ventilation) and practice on mannequins.

Toy et al. (2017) conducted a simulation-based training on 24 second-year and third-year medical students which consisted of six 4-hour training sessions on four procedural skills (intubation, arterial line placement, lumbar puncture, and central line placement). The result showed a statistically significant improvement in the knowledge scores and the procedural checklist score for intubation after the training. The students also felt significantly more confident in performing the procedure on a simulator and also on real patients.

The traditional way of learning procedural skills is through exposure to clinical practice during their working time and it is often summarised in this phrase 'see one, do one, teach one'. This phrase describes a learning method where a trainee will observe a procedure, perform the procedure themselves under supervision, and subsequently teach another trainee how to do the procedure. This kind of model might applicable for common procedures that will be encountered daily such as venepuncture or intravenous cannula insertion, but this model is not applicable for rare and life-saving procedures such as intubation (Kory et al. 2007; Yang et al. 2016). This is because trainees have to depend on the chance to encounter certain cases for a rare procedure to gain clinical experience. Psychomotor skill should be learned by performing the procedure on a real patient. However, allowing untrained personnel to perform RSI on a real patient will impose a risk of harm to the patient, which go against the principle of 'first, do no harm' in medicine. Simulation training is the way forward in learning airway management training (Yang et al. 2016). It helps all the trainees to have an equal chance of performing procedure instead of having to wait for the opportunity to do it on a real patient (Lateef 2010). It was shown that computerized patient simulator is more effective in training medical residents than the traditional experiential method (Kory et al. 2007).

With the limitation of clinical exposure due to COVID-19 pandemic, the training in airway management and RSI needs to be optimised to maximise the HO learning and training in ED rotation. Adjusting the training to the pandemic will require planning, creativity, flexibility, collaboration, and tolerance of uncertainty (Hall et al. 2020). In the setting of physical and social distancing during this pandemic, technology, existing e-learning resources, and simulation can be utilised in medical training (Cleland et al. 2020; Hall et al. 2020). Self-instruction video was shown 
to be as effective as the face-to-face method in teaching and learning basic emergency skills (Mohd. Saiboon et al. 2014). Pre-recorded video lecture on airway management and RSI can be utilised to ensure every HO will have an opportunity to receive the teaching on this topic. Each HO can watch this video and study this topic at their own pace. Regular in-house course on airway management and RSI with hands-on practical sessions for all HO in ED rotation can be conducted by emergency physicians or emergency trainees by optimising the skill lab and airway mannequins that are available in the teaching hospital.

\section{LIMITATIONS}

This was a single-centre study, and it was conducted in a teaching university hospital, which is equipped with a skill lab that allows hands-on practice and simulation training on mannequins. The result might not be applicable for hospitals which do not have such a facility for training. This study coincided with the COVID-19 pandemic but we do not have data before the pandemic. Hence, we were not able to compare the intubation experience among the HO before and during the pandemic.

\section{CONCLUSION}

This study showed that after three months of rotation in ED of HCTM, there was an improvement in both knowledge and confidence level in RSI among the HO. Most of them had medium to high level of knowledge in RSI, and the majority are competent in the skill of RSI. The clinical exposure in intubating real patients was limited among HO due to COVID-19 pandemic. Hence, it is recommended that the training of $\mathrm{HO}$ in airway management to be improvised by the use of pre-recorded video lecture and the use of simulation training with airway mannequin in the skill lab.

\section{ACKNOWLEDGEMENTS}

The authors would like to thank Nurul Saadah Ahmad from the Research Unit Department of Emergency Medicine, UKM for her invaluable statistical input in this study.

\section{REFERENCES}

Abd Samat, A.H., Isa, M.H., Sabardin, D.M., Jamal, S.M., Jaafar, M.J., Hamzah, F.A., Mahmud, A., Sanip, A., Syed Ali, S.M. \& Saiboon, I.M. 2020. Knowledge and confidence level among emergency healthcare workers in airway management and resuscitation of suspected COVID-19 patients: A cross sectional study in Malaysia. Annals of the Academy of Medicine, Singapore 49(9): 643-651.
Cleland, J., Mckimm, J., Fuller, R., Taylor, D., Janczukowicz, J. \& Gibbs, T. 2020. Adapting to the Impact of COVID-19: Sharing stories, sharing practice. Medical Teacher 42(7): 772-775.

Cucinotta, D. \& Vanelli, M. 2020. WHO Declares COVID-19 a Pandemic. Acta Biomedica 91(1): 157-160.

Hall, A.K., Nousiainen, M.T., Campisi, P., Dagnone, J.D., Frank, J.R., Kroeker, K.I., Brzezina, S., Purdy, E. \& Oswald, A. 2020. Training disrupted: Practical tips for supporting competency-based medical education during the COVID-19 pandemic. Medical Teacher 42(7): 756-761.

Kory, P.D., Eisen, L.A., Adachi, M., Ribaudo, V.A., Rosenthal, M.E. \& Mayo, P.H. 2007. Initial airway management skills of senior residents: Simulation training compared with traditional training. CHEST 132(6): 1927-1931.

Krejcie, R.V. \& Morgan, D.W. 1970. Determining sample size for research activities. Educational and Psychological Measurement 30(3): 607-610.

Lateef, F. 2010. Simulation-based learning: Just like the real thing. Journal of Emergencies, Trauma, and Shock 3(4): 348-352.

Makwana, H.D., Suthar, N.N., Gajjar, M.P. \& Thakor, A.V. 2016. Developing competency in interns for endotracheal intubation: An educational article. International Journal of Applied and Basic Medical Research 6(3): 201-204.

Malaysian Medical Council. 2008. A Guidebook for House Officers. Kuala Lumpur: Malaysian Medical Council.

Mohd Saiboon, I., Jaafar, M.J., Ahmad, N.S., Nasarudin, N.M., Mohamad, N., Ahmad, M.R. \& Gilbert, J.H. 2014. Emergency skills learning on video (ESLOV): A singleblinded randomized control trial of teaching common emergency skills using self-instruction video (SIV) versus traditional face-to-face (FTF) methods. Medical Teacher 36(3): 245-250.

Toy, S., Mckay, R.S., Walker, J.L., Johnson, S. \& Arnett, J.L. 2017. Using learner-centered, simulation-based training to improve medical students' procedural skills. Journal of Medical Education and Curricular Development 4: 2382120516684829.

Walls, R.M. 2012. Rapid sequence intubation. In Manual of Emergency Airway Management, 4th ed., edited by Walls, R.M. \& Murphy, M.F. Philadelphia (PA): Lippincott Williams \& Wilkins. p. 221.

Yang, D., Wei, Y.K., Xue, F.S., Deng, X.M. \& Zhi, J. 2016. Simulation-based airway management training: Application and looking forward. Journal of Anesthesia 30(2): 284-289.

Department of Emergency Medicine

Universiti Kebangsaan Malaysia Medical Centre

56000 Cheras, Kuala Lumpur, Federal Territory

Malaysia

*Corresponding author; email: khaldun_ismail@yahoo.com

Received: 1 February 2021

Accepted: 14 September 2021 